\begin{abstract}
Шевченко Марина Іванівна
https://orcid.org/0000-0003-0960-513X

кандидат культурології, дочент,
\end{abstract}

Київський національний університет культури і мистецттв,

Київ, Україна,

ua.kiev.marina@gmail.com

\title{
КУЛЬТУРНА ПОЛІТИКА УКРАЇНИ В УМОВАХ ЄВРОІНТЕГРАЦЇ̈: ДИЛЕМИ ТА ВИКЛИКИ
}

У статті, 3 метою з'ясування сучасного стану української культурної політики, розглянуто питання ефективності входження України в європейське співтовариство, проаналізовано рівень сформованості позитивного іміджу країни в очах міжнародної спільноти. За допомогою наукових методів теоретичного узагальнення, порівняльного аналізу та синтезу визначено проблеми, які перешкоджають розвитку культурної сфери та іiі входженню до європейського культурного простору; проаналізовано правову базу культурної політики України на предмет ії відповідності європейським вимогам та засадам; досліджено перспективи становлення культурної дипломатії як інструмента політики «м'якої сили» 3 метою формування позитивного іміджу України у світі. У ролі висновків на основі проведеного аналізу здійснено спробу окреслення шляхів оптимізації культурної політики, так як євроінтеграція є важливим напрямом розвитку України, значить створення Українського інституту закордоном мало б стати ключовою ціллю, яка має на меті формування позитивного іміджу України закордоном.

Ключові слова: культурна політика, виклики, євроінтеграція, правова база, культурна дипломатія, імідж.

Shevchenko Maryna, Candidate of Cultural Studies, Associate Professor, Kyiv National University of Culture and Arts, Kyiv, Ukraine

Cultural policy of Ukraine under conditions of the European integration: dilemmas and challenges

To find out the current state of the Ukrainian cultural policy, the article looks into the question of the effectiveness of Ukraine's entry into the European community and analyses the level of the country's positive image formation in the eyes of the international community. With the help of scientific methods of theoretical synthesis, comparative analysis and synthesis, there were identified the problems hindering the development of the cultural sphere and its entry into the European cultural space; there was analysed the legal basis of Ukrainian cultural policy for its compliance with European requirements and principles; there were studied the cultural diplomacy prospects of becoming as a tool 
of soft power policy in order to form a positive image of Ukraine in the world. As a conclusion on the basis of the analysis, there has been made an attempt to outline ways of optimizing cultural policy, as European integration is an important direction for Ukraine's development. Therefore, the creation of a Ukrainian institute abroad should become a key goal, aimed at forming a positive image of Ukraine abroad.

Key words: cultural policy, challenges, European integration, legal framework, cultural diplomacy, image.

Шевченко Марина Ивановна, кандидат культурологии, дочент, Киевский национальный университет культуры и искусств, Киев, Украина

Культурная политика Украины в условиях Евроинтеграции: дилеммы и вызовы

В статье, с целью выяснения современного состояния украинской культурной политики, рассмотрены вопросы эффективности вхождения Украины в европейское сообщество, проанализирован уровень сформированного положительного имиджа страны в глазах международного сообщества. С помощью научных методов теоретического обобщения, сравнительного анализа и синтеза определены проблемы, которые препятствуют развитию культурной сферы и ее вхождению в европейское культурное пространство; проанализировано правовую базу культурной политики Украины на предмет ее соответствия европейским требованиям и принципам; исследованы перспективы становления культурной дипломатии как инструмента политики «мягкой силы» с целью формирования положительного имиджа Украины в мире. В качестве выводов на основе проведенного анализа предпринята попытка определения путей оптимизации культурной политики, так как евроинтеграция является важным направлением развития Украины, значит создание Украинского института за рубежом должно стать ключевой целью, которая имеет в виду формирование позитивного имиджа Украины за рубежом.

Ключевые слова: культурная политика, вызовы, евроинтеграция, правовая база, культурная дипломатия, имидж.

Вступ. Темпи інтеграції України з Свропейським Союзом залежать від низки факторів. У науковій літературі, у засобах масової інформації віднаходимо безліч різноманітних передумов, здійснення яких об'єктивно мало б відкрити дорогу Україні до об'єднаної Європи. Це дійсно такі важливі критерії як високий рівень дотримання прав та свобод людини, забезпечення політичної та економічної стабільності, викорінення корупції тощо. Однак, результати референдуму, проведеного у квітні 2016 р. у Нідерландах щодо затвердження Угоди про асоціацію між Україною та Європейським Союзом, засвідчили ще одну, не менш важливу проблему. Ефективність входження України у європейське співтовариство 


\section{КУЛЬТУРНА ПОЛІТИКА УКРАЇНИ В УМОВАХ ЄВРОІНТЕГРАЦІЇ: ДИЛЕМИ ТА ВИКЛИКИ}

залежатиме від вміння репрезентуватися на міжнародній арені, здійснювати інформаційний вплив, а також наявності сформованого позивного іміджу в очах міжнародної спільноти як демократичної держави, надійного та відповідального партнера.

Порушена вище проблема видається досить актуальною як з прикладної, так і з теоретичної точки зору. Адже іiі вирішення потребує цілого комплексу дій, починаючи від окреслення ключових положень i напрямів реалізації, так і безпосереднього їх впровадження. Досвід провідних країн показує, що все частіше у світовій політиці їх уряди вдаються до застосування політики так званої soft power, тобто «м'якої сили». На відміну від політики «жорсткої сили», інструментом досягнення цілей якої зазвичай виступає примус, політика «м'якої сили» спирається натомість на такі засади як співробітництво, створення привабливості іміджу за допомогою культурних цінностей, традицій тощо. Політика «м'якої сили» $є$ гнучкою і здатною швидко реагувати на нові виклики чи загрози, але їі реалізація, як і досягнення поставлених цілей, є довгостроковим процесом. Повертаючись до проблеми, яка стала очевидною в результаті референдуму в Нідерландах, формування позитивного іміджу України, на нашу думку, як і поширення свого впливу у світі лежить в основі належно окресленої культурної політики, ї̈ внутрішніх та зовнішніх орієнтирів, відкритості на пізнання нових цінностей, як і розповсюдження власних надбань та досягнень.

Тому актуальність цього наукового дослідження зумовлено відсутністю сформованого бачення та розуміння орієнтирів розвитку української культурної політики на шляху інтеграції нашої країни до європейського простору, в тому числі культурного. Зближення 3 Європейським Союзом ставить за необхідність гармонізувати та удосконалити національну культурну політику відповідно до тих принципів та засад, які діють як на рівні всього союзу, так і в державах-членах. Таке визначення проблеми дозволяє зробити припущення, що збереження в подальшому так званого принципу «залишковості», як його часто називають науковці, в процесі розроблення і втілення української культурної політики відбиватиметься на гальмуванні всього процесу європейської інтеграції.

Аналіз попередніх досліджень і публікацій. Проблематика культурної політики, зокрема ï принципи та засади формування в Україні, достатньо розкрита в працях багатьох українських науковців. До цього переліку віднесемо таких як: В. Андрущенко, Т. Возняк, О. Гриценко, Л. Губерський, I. Костиря, М. Михальченко, М. Худолій, 3. Широченко та інші. Окремі аспекти культурної політики України пов'язані 3 процесами глобалізації, євроінтеграції висвітлені Ю. Богуцьким, С. Здіоруком, В. Малімоном, В. Мельник, М. Поплавським, Л. Хашиєвою, а також багатьма іншими. Зважаючи на те, що процеси євроінтеграції здійснюються активними темпами, нові виклики виникатимуть постійно, які не можуть залишатися поза увагою науковців. 
Мета наукового дослідження - 3'ясувати сучасний стан української культурної політики та витоки тих дилем, які ймовірно очікують на неї або вже почали проявлятися в умовах євроінтеграції.

Викладення матеріалу дослідження. Відомий чеський державний діяч В. Гавел, ще коли він не був президентом Чеської республіки, а дисидентом, який боровся за такі цінності як «свобода», «правда», писав про культуру як «основний інструмент самоусвідомлення суспільства». «Культура, як конкретна галузь людської діяльності, що впливає - хай часто й досить опосередковано - на загальний стан духу, і водночас постійно перебуває під впливом цього стану» (Havel, 2016, p. 24). 3 міркувань В. Гавела, культура постає не просто як сфера, яка спроможна задовольнити, наприклад, духовні чи моральні потреби суспільства, а як сфера, призначення та місія якої є значно більшими. Ми солідарні з позицією В. Гавела, яка в черговий раз засвідчує значущість потенціалу культури, зокрема в державотворчих процесах, коли існує необхідність в усвідомленні доцільних орієнтирів розвитку держави.

Унікальність культури українського народу не піддається жодним сумнівам. Виражена багатокультурна різноманітність є тим чинником, який відрізняє українців від інших народів, але може і повинна також стати чинником, який консолідує українське суспільство. У процесі регіоналізації, глобалізації, коли зникають як такі перешкоди для поширення культурних цінностей, питання збереження національної культурної ідентичності напевно відноситься до стратегічно важливих.

За таких умов, культурна політика держави мала б бути спрямованою на підтримку національного культурного продукту. Однак, якщо проаналізувати аналітичну доповідь, підготовлену за редакцією С. Здіорука для Національного інституту стратегічних досліджень на тему «Культурна політика України: національна модель у європейському контексті», виявляється скільки існує проблемних питань, на яких варто зупинитися детальніше. Передусім виділимо той факт, що поза сферою компетенції, але й також увагою відповідних органів влади залишаються багато культурних подій та явищ, які в Свропі давно розглядаються як невід'ємна частина цієї сфери (віртуальні музеї, цифрове мистецтво тощо). По-друге, відсутня відповідальності у сфері культури, що не в останню чергу пов'язано з браком чіткого розподілу повноважень між органами державної влади різних рівнів. По-третє, громадські організації, діяльність яких орієнтована на культурну сферу, не мають окремої специфіки і розглядаються так само як інші громадські організації. По-четверте, недосконалість чинного законодавства у сфері охорони культурної спадщини спричинює різного роду конфлікти між суб'єктами, які б мали здійснювати функцію охорони (Zdioruk, 2012, pp. 18-20). Узагальнюючи перелічені проблеми, видається за доцільне сформулювати тезу про те, що в Україні культурна політика позбавлена чіткої візії, як i яким чином розвивати та підтримувати цю сферу. Дане твердження походить 3 того, що відсутня чітка 


\section{КУЛЬТУРНА ПОЛІТИКА УКРАЇНИ В УМОВАХ ЄВРОІНТЕГРАЦЇ̈: ДИЛЕМИ ТА ВИКЛИКИ}

відповідальність, а це означає прагнення усіх займатися будь-якими питаннями культури, але не нести відповідальності за свої дії. Збереження і надалі такого підходу в культурній політиці, яка передусім полягає у здійсненні ряду адміністративних дій, характеризуватиметься хаотичністю та окремою ініціативністю.

Можливо проблеми такого стану пов'язані 3 неналежним розумінням культурної політики, місцем та ступенем втручання держави у культурну сферу. У цьому контексті варто проаналізувати і закордонний досвід. Так, польський науковець Д. Пшастек розглядаючи розуміння культурної політики приходить до висновку, що «в демократичній державі важко говорити про єдину, спільну модель культурної політики». Свою думку він аргументує двома причинами. По-перше, відсутність такої єдності походить з адміністративно-територіального поділу держави, коли засновниками інституцій культури можуть бути як держава, так і органи місцевого самоврядування. А по-друге, часто змінюється керівництво центральних органів державної влади у сфері культури і відповідно змінюються їх інтереси, напрями розвитку культурної політики (Przastek, 2016, p. 10). Розмірковуючи далі над поняттям культурної політики, польський науковець звернувся до ще однієї важливої проблеми: чи за вище перелічених умов доцільно використовувати термін «культурна політика» чи «культурні політики»? У своїх міркуваннях Д. Пшастек переконливо доводить, що термін «культурна політика» більше асоціюється з недемократичними режимами, коли сфера культури $\epsilon$ однорідною, а її спрямованість зазвичай зорієнтована на підтримку дій правлячої еліти. Іншими словами, за такого підходу відсутня можливість розвитку плюралістичної моделі культурної політики. Однак в сучасних демократичних державах, в яких розвинута сильна модель децентралізації державної влади, багато компетенцій у сфері культури передаються 3 центрального рівня на місцевий. Звертаючись до досвіду Польщі, Д. Пшастек вважає, що в цій сусідній з нами країні все-таки ближчим є термін «культурна політика», оскільки, на його думку, «надалі існують сильні тенденції доктринального та ідеологічного підпорядкування мистецтва політикам різного щабля» (Przastek, 2016, p. 11).

Повертаючись до України, то ситуація видається більш ніж очевидною. Залишки попередньої епохи тоталітаризму настільки міцно укорінилися в структурі і діяльності органів державної влади, що методи та підходи до розроблення державної політики у будь-якій сфері залишилися без радикальних змін. Відповідно для України, на нашу думку, також буде ближчим термін «культурна політика», яка формується на рівні центральних органів державної влади та охоплює, а також стосується всіх інституцій, які діють на території держави. Підтвердження цього можемо знайти як на рівні законодавства, так і серед наукової літератури. У Законі України «Про культуру» визначено основні засади державної політики у сфері культури, як і iii пріоритети (Zakon Ukrainy Pro kulturu). Так само і більшість 
наукових статей, присвячених культурній політиці містять у своїй назві слово «державна». Однак 3 початком реформи децентралізації влади в Україні, яка торкнеться і культурного сектору, радше за все поступово відбудуться зміни у складі суб'єктів, відповідальних за формування культурної політики.

На початку 2017 р. відбулася стратегічна сесія, на якій розглядалося питання проведення децентралізації у сфері культури. За інформацією, яка доступна на урядовому сайті «Децентралізація влади», в наступні кілька років очікується проведення реформи децентралізації у сфері культури, яка супроводжуватиметься розподілом повноважень між різними рівнями влади, передачею установ культури з державного бюджету у комунальну власність, реалізацією низки цільових програм тощо (Prezentovano Kontseptsiiu...). Проте, з доступних джерел інформації не відомо, чи зміниться підхід до формування засад культурної політики, як на рівні держави, так і на рівні органів місцевого самоврядування.

Розглядаючи питання існування однієї культурної політики в рамках держави чи культурних політик, може виникнути чергова дискусія щодо доцільності того чи іншого підходу. Видається за належне зазначити, що на шляху до входження України в європейський культурний простір порушена проблема неодмінно з'явиться, оскільки культура радше не належить до тих сфер, коли імперативом на визначення пріоритетів політики у цій сфері володіє виключно держава. Культура це зрештою сфера, де ініціативи мають походити радше «не зверху», а «знизу», коли й саме суспільство $є$ зацікавленим у творенні матеріальних чи духовних культурних благ.

Закордонні аналітики, зокрема координатор експертної групи розвитку культурних і творчих індустрій Єврокомісії Рагнар Сіiл, аналізуючи культурну політику в Україні прийшов до такого висновку. Якщо розглядати культурну політику в широкому розумінні як будь-які рішення, які приймаються у сфері культури, тоді в Україні вона існує. Проте, якщо розглядати ії у вузькому розумінні як існування на рівні документу, то тоді іï немає (Trehub, 2016). Дозволимо погодитися з міркуваннями естонського фахівця у першому і другому трактуванні культурної політики. Адже в Україні дійсно $є$ центральні, обласні та місцеві органи виконавчої влади у сфері освіти, ними приймаються певні рішення, але немає окреслених орієнтирів, які дозволили б оцінити вірність та належність прийнятих політичних рішень. Здійснюючи пошуки існуючих державних цільових програм у сфері культури можемо натрапити на Концепцію державної політики в галузі культури на 2005-2007 pp. Часові рамки реалізації цієї програми вже давно минулися, але ії статус на офіційному сайті українського законодавства зазначається як «чинний». Хоча в 2016 р. уряд все-таки схвалив Довгострокову стратегію розвитку української культури - стратегію реформ. На рівні областей окремих програм розвитку культурної галузі радше немає, оскільки ця сфера входить до загальної стратегії розвитку області. Для порівняння звернемося до вже 


\section{КУЛЬТУРНА ПОЛІТИКА УКРАЇНИ В УМОВАХ ЄВРОІНТЕГРАЦЇ̈: ДИЛЕМИ ТА ВИКЛИКИ}

кількаразово згаданої Польщі, в якій прийнята Національна стратегія розвитку культури на 2004-2022 рр., а на рівні регіонів - воєводств - прийняті сеймиками окремі стратегії розвитку культури.

Залишаючи аналіз змісту згаданих документів для іншого дослідження, зазначимо наступне. Культурна політика в Україні потребує особливого переосмислення як зі сторони правлячої еліти, так і самого суспільства. Культурна політика не існує відірвано, а тісно входить в комплекс всієї державної політики i iii результативність, ефективність так само відображається на результативності й ефективності інших державотворчих процесів. Недаремно О. Валевський прямо вказує, що «одна 3 причин невдач модернізації українського суспільства полягає в тому, що не приділялось належної уваги необхідності реформувати культурну політику» (Valevskyi, 2014, p. 42).

Розглядаючи внутрішньодержавні проблеми культурної політики, не можна обминати i зовнішніх, які в процесі євроінтеграції є відчутними i здатними негативно впливати на сприйняття нашої країни у світі. Саме тому, йдеться про можливості реалізації у світовому просторі політики «м'якої сили», використовуючи такий інструмент як культурна дипломатія. Одразу зазначимо, що призначення культурної дипломатії набагато дальше виходить за просто популяризацію культури, тому що це також інструмент вирішення важливих і економічних, і політичних справ. Проблематика культурної дипломатії порушена нами не випадково, оскільки культурна політика - це не тільки зацікавленість держави у розвитку культурної сфери, але й також суспільства. Так само і культурна дипломатія, яка приходить в доповнення діяльності офіційної дипломатії та поєднує як цілеспрямовану діяльність органів державної влади, так і діяльність членів суспільства закордоном, які є носіями та уособленням певної національної культурної ідентичності.

У ще одній аналітичній доповіді Національного інституту стратегічних досліджень, тільки вже під редакцією О. Розумної на тему «Культурна дипломатія України: стан, проблеми, перспективи» зазначається, що «культурна дипломатія може і має бути складовою культурної політики держави, але лише у тому разі, якщо та відповідає актуальним потребам соціуму» (Rozumna, 2016, p. 5).

Термін «культурна дипломатія» для українського наукового середовища видається досить новим, а його активне вивчення розпочалося мабуть із початком російської агресії в Україну, коли виникла вкрай важлива потреба у формуванні та підтриманні позитивного іміджу нашої країни у світі. Г. Шамборський та Н. Мусієнко, наприклад, розглядають культурну дипломатію як «процес міжнародних комунікацій, що включає в себе діяльність, спрямовану на просування іміджу країни, формування іiі авторитету та довіри до неї, а також можливість зрозуміти культуру, цінності та цілі інших країн та народів світу». При цьому вони відмічають і наголошують, що «культурна дипломатія своїм завданням повинна 
мати збереження та розвиток національної культурної спадщини в Україні та за кордоном» (Shamborovskyi, 2015, p. 93).

Реалізація культурної дипломатії має велику кількість форм, каналів і шляхів реалізації. Однак, коли йдеться про форму, за якої можливе співробітництво закордонних українців та офіційних органів державної влади - це створення українських інститутів закордоном. Зазначене питання широкого обговорюється громадськістю, оскільки створення таких інститутів $є$ питанням просування інтересів України закордоном. Необхідність цих інститутів викликана тим, що офіційні дипломатичні установи України нездатні забезпечити реалізацію всіх цілей культурної дипломатії. Більше того, треба зазначити, що ці інститути мають бути зорієнтовані не на українців, які проживають закордоном, а саме на громадян тих країн, де вони функціонують. Адже, якщо глянути з історичної ретроспективи, то побачимо, що в багатьох містах закордоном, де $є$ скупчення української діаспори, існують центри української мови, культури тощо. Проте, ініціаторами їх створення були українці, які виїжджали і відчували необхідність у збереженні українських традицій, тобто задовольнити власні культурні потреби.

Створення Українського інституту, вибору його правової форми, окреслення завдань проходить активну фазу опрацювання. В лютому 2017 р. Міністр закордонних справ України П. Клімкін представив візію Українського інституту. «Мета створення Інституту - розуміння сучасної України і зростання довіри до України у міжнародному інтелектуальному і культурному середовищі» (Ukrainskyi instytut: miaka syla...). Важливо, що розглядуване питання об’єднало діяльність як Міністерства культури, так і Міністерства закордонних справ і широке коло громадськості.

Завдання культурної дипломатії виходять за рамки діяльності Українського інституту, але його місія, як і початок функціонування зможуть активізувати присутність України у міжнародній спільноті. Візьмімо для прикладу такі інституції як Польський інститут, Гете-інститут, Французький інститут, діяльність яких знана широкому колу людей та дозволяє створювати позитивний імідж їх країн за кордоном.

Висновки. Отож, підсумовуючи, можна зробити висновок. Розглянуті нами проблеми і виклики, які можуть постати перед культурною політикою України в умовах інтеграції є очевидними і реальними. 3 іншої сторони, компетентні органи державної влади у сфері культури усвідомлені з ними і можна побачити певні зрушення на шляху їх вирішення. Але для цього потрібна не тільки політична воля, але й бажання самого суспільства звернути на культурну сферу більше уваги. Звичайно, питання фінансування, яке здатне вирішити багато проблем $є$ складним, беручи до уваги поточну ситуацію, в якій перебуває України. За таких умов, доцільним видається хоча б визначення з конкретними, пріоритетними орієнтирами, які допоможуть оптимізувати культурну політику та зосередити ресурси 


\section{КУЛЬТУРНА ПОЛІТИКА УКРАЇНИ В УМОВАХ ЄВРОІНТЕГРАЦЇ̈: ДИЛЕМИ ТА ВИКЛИКИ}

на стратегічного важливих шляхах. Наприклад, євроінтеграція є важливим напрямом розвитку України, значить створення Українського інституту закордоном мало б стати ключовою ціллю, яка має на меті формування позитивного іміджу України закордоном. Таким чином, культурна політика не може i не повинна бути «залишковою сферою» державної політики, оскільки їі потенціал здатний сприяти виконанню багатьох завдань.

\section{References:}

1. Havel, V. (2016). Promovy ta esei [Speeches and essays]. Translated from Czech by Radko Mokryk, Tetiana Okopna, Yevhen ta Olha Perebyinis. Kyiv: "KOMORA" Publishing house.

2. Prezentovano Kontseptsiiu «Detsentralizatsiia: sektor Kultura» (+infohrafika). (2017). Decentralisation, [online] Available at: <http://decentralization.gov.ua/news/item/id/4038> [Accessed 20 October 2018].

3. Przastek, D. (2016). 'Polityka kulturalna w Polsce (i na świecie)'. Studia BAS, no. 2(46), pp. 9-35.

4. Rozumna, O. P. (2016). 'Kulturna dyplomatiia Ukrainy: stan, problemy, perspektyvy'. National Institute for Strategic Studies, [online] Available at:http://www.niss.gov.ua/content/articles/files/kultu_dypl-26841.pdf. [Accessed 20 October 2018].

5. Shamborovskyi, H. (2015). 'Zavdannia i mozhlyvosti kulturnoi dyplomatii u rozvytku suchasnoi derzhavy ta instytutiv hromadianskoho suspilstva v Ukraini' [Challenges and Possibilities of Cultural Diplomacy in the Development of the Contemporary State and Institutions of Civil Society in Ukraine ]. (2015). Ahora, issue 14, pp. 91-100.

6. Trehub, H. (2016). 'Ragnar Siil: "Kultura tsinna sama po sobi, vona ne yde pislia sytoho shlunka, zdorovia toshcho" [Ragnar Seal: "Culture is valuable by itself, it does not go after a nourishing stomach, health, etc.]. Tyzhden.ua, [online] Available at:<http://tyzhden.ua/Culture/174452> [Accessed 23 October 2018].

7. Ukrainskyi instytut: miaka syla dlia prosuvannia suchasnoi Ukrainy u sviti [Ukrainian Institute: soft power for the advancement of modern Ukraine in the world]. (2017). Ministry of Foreign Affairs of Ukraine, [online], Available at: <http://mfa.gov.ua/ua/press-center/news/54574-ukrajinsykij-institut-mjaka-sila-dlyaprosuvannya-suchasnoji-ukrajini-u-sviti> [Accessed 22 October 2018].

8. Valevskyi, O. (2014). 'Kulturna polityka yak osnova stratehii modernizatsii ukrainskoho suspilstva' [Cultural policy as the basis of the strategy of modernization of Ukrainian society]. Publichne upravlinnia: teoriia ta praktyka [Public Administration: Theory and Practice], issue 2 (a special issue), pp. 42-47. 
9. Zakon Ukrainy Pro kulturu : vid 14 hrudnia 2010 roku № 2778-VI [Law of Ukraine On Culture from December 14 2010, no. 2778-VI]. Vidomosti Verkhovnoi Rady Ukrainy. Kyiv: Parliamentary Publishing.

10. Zdioruk, S. I. (2012). Kulturna polityka Ukrainy: natsionalna model u yevropeiskomu konteksti [Cultural Policy of Ukraine: A National Model in the European Context]. Kyiv : National institute for Strategic Studies.

(С) Шевченко М. І., 2019 